ENTREPRENEURSHIP AND SUSTAINABILITY ISSUES

ISSN 2345-0282 (online) http://jssidoi.org/jesi/

2021 Volume 8 Number 4 (June)

https://doi.org/10.9770/jesi.2021.8.4(2)

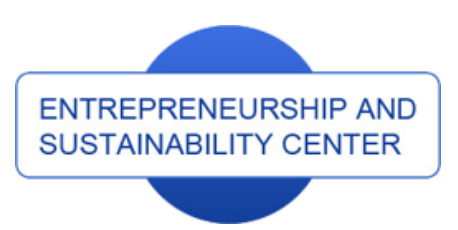

Publisher

http://jssidoi.org/esc/home

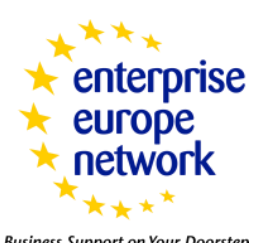

Business Support on Your Doorstep

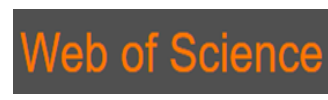

Clarivate

\title{
BUSINESS MODELS OF START-UPS AND THEIR IMPACT ON THE SUSTAINABILITY OF NASCENT BUSINESS*
}

\author{
Štefan Slávik ${ }^{1}$, Richard Bednár ${ }^{2}$, Ivana Mišúnová Hudáková ${ }^{3}$, Branislav Zagoršek ${ }^{4}$ \\ 1,2,3,4 Department of Management, University of Economics in Bratislava, 85102 Bratislava, Slovakia \\ E-mails: ${ }^{1}$ stefan.slavik@euba.sk; ${ }^{2}$ richard.bednar@euba.sk; ${ }^{3}$ ivana.hudakova@euba.sk; ${ }^{4}$ branislav.zagorsek@euba.sk
}

Received 20 September 2020; accepted 23 February 2021; published 30 June 2021

\begin{abstract}
Start-ups are an attractive business phenomenon because they offer opportunities for personal self-realization and extraordinary business growth. The survival and sustainability of start-ups depends mainly on the quality and development of their business model. However, this assumption must be confirmed by the field research. Field research dealt with the personnel background of the business, the business idea, the structure of the business model, the impact of quality and development degree of business model on start-up performance. Each start-up was individually examined on the basis of a structured questionnaire and a personal interview with the founder. Start-up founders are relatively young and educated, but without relevant business experience. The originality of business ideas is approaching the European level, but the evidence about it is superficial and the degree of protection of ideas is low. The level of quality and development of business model blocks is unbalanced. The most developed block is the customer value proposition/product, the least developed block is the revenue streams. The business model affects the performance of the start-up, but in a small intensity and efficiency only. The examined start-ups are slow in their development and fail to sufficiently monetize the results of their efforts. Research has revealed new and original insights into the structure of the business model of start-ups, the links between the quality of blocks and their stage of development, the impact of the business model on start-up performance or sustainability, and identified some weaknesses of startups. Faster development of business model and purposeful selection of partners and effective cooperation with them would probably eliminate at least some of the shortcomings of the start-ups under investigation.
\end{abstract}

Keywords: start-up; business idea; business model; canvas; business performance; sustainability of business

Reference to this paper should be made as follows: Slávik, Š., Bednár, R., Mišúnová Hudáková, I., Zagoršek, B. 2021. Business models of start-ups and their impact on the sustainability of nascent business. Entrepreneurship and Sustainability Issues, 8(4), 29-52. https://doi.org/10.9770/jesi.2021.8.4(2)

\footnotetext{
* This research was supported by the Nadácia Manažér/Foundation of Manager, Faculty of Business Management, University of Economics in Bratislava, Slovak Republic, grant number 1/18. In addition, this research was supported by the Scientific grant agency of Ministry of Education of Slovak Republic and Slovak Academy of Sciences (VEGA), grant number 1/0063/19.
} 


\section{ENTREPRENEURSHIP AND SUSTAINABILITY ISSUES}

ISSN 2345-0282 (online) http://jssidoi.org/jesi/

2021 Volume 8 Number 4 (June)

https://doi.org/10.9770/jesi.2021.8.4(2)

JEL Classifications: M10, G24

\section{Introduction}

Start-up is a business experiment and a very small beginning enterprise that provides space for self-realization, an opportunity to develop and implement unusual and risky ideas, for uncommon satisfying of existing needs and discovering new needs. Start-ups contain potential for exceptional growth but also unforeseen and repeated failures. They are a living laboratory to investigate the establishment and maturation of a business. The progress, success and sustainability of a start-up usually depends on the quality of its business model, team and business strategy. Among these three determinants of business performance, the research focuses on the role of the business model as it is considered a primary prerequisite for the existence of a start-up. Start-up as an incomplete and imperfect enterprise must realize its business idea by creating a business model that contains all the components and conditions that are necessary for the functioning of the company. An effective business model will provide the customer with the value that the customer accepts and pays for it, while the company will cover all of its costs and earn a profit. The aim of the research, the results of which are presented in this article, is to examine the structure of the start-up business model icluding business idea, its impact on the business performance and personnel background of the startup.

\section{Role of the business model in start-ups}

Start-up is a team of people (P. Thiel, 2014, p. 10-11) who have associtated to achieve an unusual goal through extraordinary intellectual effort and unconventional corporate culture. Start-up is a human institution designed to create a new product or service in conditions of extreme uncertainty (E. Ries, 2011, p. 27). The Twin Enterpreneurs Regional Study reports that start-up is a young, no more than seven-year-old enterprise with a scalable business model, built on innovation or a new product that has global ambitions (Dömötör et al., 2013). N. Thanader (2012), who himself launched a successful start-up, considers their main goals as the biggest difference between a start-up and a small company. Small companies aim to be profitable and have a stable long-term value. Start-ups focus on revenue and growth potential. Wayra is an accelerator that specializes in supporting start-ups. It sets out the following conditions for entry into its environment: companies or projects must be at an early stage of development, preferably with differentiated technology and significant innovation, the product must be scalable, have potential for growth, and have the precondition for rapid growth and revenue generation (speedinvest.com/ proceed).

Start-up works in an environment of ambiguity or uncertainty, but at the same time it seeks to find concrete and usable solutions, grows dynamically and tentatively borderlessly, employs people who give up ordinary job security at the expense of exciting personal growth and achieving concrete results. It can, but may not work on the base of, technology and ceases to be a start-up after crossing certain boundaries (acquisitions, sales, profits, number of employees and others). Start-up distinguishes from a typical small and medium-sized enterprise (www.podnikajte.sk) a unique and innovative product with the potential of dynamic and global growth with an expected revenue of several tens of millions of euros. However, such performance can usually be achieved only through the internationalization of business making (Crick \& Crick, 2018).

The KPMG research report (2014, p. 34) states that the weaknesses of start-ups are financial planning, expansion into new markets, fundraising, business modelling and other shortcomings. In the KPMG 2016 report (p. 3), the biggest challenges are finding a profitable and repeatable business model, scaling, sales growth and new customer acquisition. Similarly, the Booming Berlin report (2016, p. 9) on the Berlin start-up scene assumes that with a functioning business model, the start-up will evolve into a growing business within five years. 


\section{ENTREPRENEURSHIP AND SUSTAINABILITY ISSUES}

ISSN 2345-0282 (online) http://jssidoi.org/jesi/

2021 Volume 8 Number 4 (June)

https://doi.org/10.9770/jesi.2021.8.4(2)

Sedlacek and Sterk (2014) note start-ups as an important source of employment growth in their research study. Dent et al. (2016) examined the role of start-ups in structural transformation and its implications for employment. Fritsch and Wyrwich (2018) examined start-ups in the context of regional knowledge and business culture. These studies show that start-ups are a serious phenomenon in economic and business development. The positive impact of start-ups on the economic and social growth of the region and the country is also confirmed in the work of Cavallo et al. (2020).

Groesser and Jovy (2015) consider the business model to be a substantial part of the company, regardless of whether the company is a small entity or a global giant. Key interaction is the link between supply and demand. Korhonen et al. (2017) consider it very important to attract a large mass of customers, provide them with completely new services, open up new markets and foster business-customer interactions in a variety of ways, notably through digital platforms. The business model is usually visualized for clarity and ease of use. Afuah (2014, p. 5) offers one of the less complex visualizations. The content of the model is the value offered to the customer, resources and activities, market segments, growth model and revenue model. The business model of Johnson et al. (2008) consists of four interconnected elements that form and provide value. Its main parts are customer value proposition, which is considered the most important, key resources, key processes and profit formula. Gassmann et al. (2014, p. 7) compiled a concept arranged in a triangle, which consists of four dimensions (three vertices and the center of gravity), which are the customer, the value offer, the value chain, the profit mechanism. Visualization is relatively simple, and therefore it is more suitable as a tool for workshops than for complex systematization. The most common visualization of the business model is the concept of canvas by Osterwalder and Pigneur (2009, pp. 15 - 44). It contains nine blocks and is a suitable compromise between summary and detailed visualization, and is therefore used as a research tool (third part of the article).

Incubators are a special chapter in the research of start-ups. Malmström and Johansson et al. (2016) have discovered interrelated challenges that limit the ability of Western European start-ups to grow into high-income businesses. They consider that incubators should be more concerned with shaping the business ecosystem than creating an environment that protects start-ups from unpleasant institutions. Another result of the research was that start-ups suffer from a lack of market orientation, a lack of entrepreneurial culture, a small domestic market, a lack of start-up capital, and universities that do not engage in entrepreneurship. Cooper and Folta (2017) and Bliemel et al. (2018) see certain solutions in the cluster cooperation, which can overcome a shortage of resources, business experience and familiarity with the market.

The key role of the business model in start-up is emphasized by Foss and Saebi (2017) when they write "For startups, any business act means choosing a business model, whereas in established companies applying business judgment will result in changes to the business model components or its structure". However, research studies do not explain the structure and implications of the business model of start-ups. Davila et al. (2015) point out that start-up enters an existing market with a business model that may prove economically unviable ex post. Kopera et al. (2018) explain that the technical rarity itself is rarely the source of success, but rather it is the business model behind an idea. The business model supports complex business efforts, the result is a better product and more efficient business model configuration. Block et al. (2014) write that the conditions at the birth of a company tend to influence companies over very long periods. The consequences of initial strategic decisions are usually very lasting. In addition, skills, customer relationships, personnel and capital investment at the start of a business will lock the company within some boundaries. It can be added that many of these conditions are clearly related to the business model. The importance of the model in start-ups is also recognized in technology transfer agencies, which carry out intensive innovation programs for entrepreneurs developing business models (Pettersen et al., 2016).

Rydehell and Isaksson's findings (2016) suggest that new technology-based firms (NTBFs) consider customer value propositions as the most valuable element of their business model. They also noted signs of financial 


\section{ENTREPRENEURSHIP AND SUSTAINABILITY ISSUES}

ISSN 2345-0282 (online) http://jssidoi.org/jesi/

2021 Volume 8 Number 4 (June)

https://doi.org/10.9770/jesi.2021.8.4(2)

partners' influence on how founders perceive initial business models. Further research results show that some NTBF companies are developing parallel business models inside to ensure their survival in the start-up phase. The findings from Malmström and Johansson (2017) highlight that cash and expertise appear to be an essential point at the design of the business model structure in the early stages of new businesses. Teece and Linden (2017) write that, in many cases, Internet-based companies are pursuing the growth of customers at the expense of profits. The road to profitability, which is at the heart of the business model, should not be an additional idea. A well designed business model balances the value provided to the customer with the value that the provider appropriates himself. Klačmer Calopa et al. (2014) came to a similar cognition: "It is difficult to find investors for a start-up that does not bring a profit as well as potential users". Euchner and Ganguly (2014) perceive the business model in a broader context and implications: "The business model is not just a means by which a company creates and appropriates a value for the customer. Concentration on customer value creation, regardless of competitive advantage, will leave the business vulnerable due to erosion of a margin and anaemic growth". In this broader context, there is also a de facto reference to the importance of business strategy.

Recognized business matadors S. Blank and B. Dorf (2012, p. XVII) write that "Start-up is a temporary organization to look for a scalable, repeatable and profitable business model." They pay close attention to scaling. According to their knowledge (2012, p. XVIII), a scalable start-up is the work of traditional technology entrepreneurs. They set up a company with the vision that they will change the world and their enterprise will generate millions, if not billions, of dollars. Scalable start-up is initially looking for a repeatable and scalable business model.

The common and unifying denominator, which is the business model, shines in the background of the outlined topics that explore the business making of start-ups. The business model is considered a serious condition for successful business making. Although the business model or its components are considered to be a significant factor in the viability of the start-up, there are not enough specific arguments to support this assertion. Published knowledge on start-ups and their business models follow from knowledge on start-ups and their business making, but they are not confirmed, verified by a field research.

\section{Objectives, research sample and methods of research}

The main aim of the research is to deepen the knowledge of business models of start-ups, because on based of the studied literature, the business model and related factors are one of the main causes of success but also the failure of start-up. The partial objectives of the research are:

1. Examining the personnel background of start-ups and circumstances of the birth of business idea as they lay foundations for building a business model.

2. Knowing the content, quality and degree of development of the business model of start-up at the level of individual blocks, identify the differences between blocks and explain them.

3. Knowing the impact of the business model on start-up performance. The model is described and quantified by the quality and degree of development of individual blocks.

The research sample contains thirty start-ups (Appendix 1) operating in Slovakia in 2018 (53.3\% start-ups are dealing with IT apps, 26.7\% with technology, 20.0\% with services, e.g. support of education, sport, administration,) The original sample contained nearly a hundred start-ups and followed up on research in 2015, 2016 and 2017 (Slávik, 2019), but had to be reduced due to failed start-ups and the reluctance of frustrated startuppers to devote their capacity to collaborating with researchers. The common feature of the researched start-ups is approximately the same age and activity in the metropolitan area with developed infrastructure and start-up scene. Each start-up was examined by one member of the research team, who personally recorded the evaluations and answers of the founder/owner to the closed and open questions in the questionnaire and immediately explained any ambiguities. 


\section{ENTREPRENEURSHIP AND SUSTAINABILITY ISSUES}

ISSN 2345-0282 (online) http://jssidoi.org/jesi/

2021 Volume 8 Number 4 (June)

https://doi.org/10.9770/jesi.2021.8.4(2)

The business model is described by means of a canvas visualization (Osterwalder and Pigneur, 2009) that divides the model into nine blocks: customer value proposition/product, customer segments, customer relationships, distribution channels, key activities, key resources, key partners, cost structure, revenues. This model is sufficiently concise, has more, but limited detailedness, and was therefore also used in the field research. Each block is described by open qualitative questions and closed quantitative questions. The responses are quantified, if possible, in real units, e.g. years. If this is not possible, they are expressed as percentages or, as a rule, on a fivepoint scale. The minimum granted value (1) means e.g. the lowest quality, simple solution, local level, high cost, common standard, mass market, etc. The maximum granted value (5) means world quality, sophisticated solution, world class, low cost, full original, customization, etc. Norman (2010) studied the use of ordinal scale as a continuous variable. He concluded that ordinal scales like Likert scale could be used in parametric statistics without the risk of getting to a wrong conclusion. Blocks of the business model are also evaluated according to the degree of completion or degree of functionality in tens of percent.

In addition to the business model, the research focused on the staffing of the start-up, the creation of a business idea, positive and negative experiences with business making and pivots (fundamental changes in the development of start-up).

The qualitative research of the business model is based on induction (deriving a general conclusion based on knowledge about particulars) and exploring unique and non-recurring phenomena. The advantage of a nonnumerical solution is high validity, detailed and in-depth knowledge, but it is associated with a disadvantage that may be of low reliability, because the result may not be generalizable. Some structure and regularity are being found in the qualitative data.

Quantitative research of business model is based on descriptive statistics, correlations, and linear regression. Descriptive statistics use the proportion (\%) of the investigated parameter to the whole research sample or its mean value to describe the investigated fact. Mean data values are generally expressed as an arithmetic mean unless otherwise indicated. In selected cases, they are expressed in median, which better expresses the mean value because the sample is small and contains some large variations.

Correlation analysis was used to investigate the relationships between the selected data (Tables 4,5 ). The Kendall's tau b test was used to calculate the correlation coefficient, which is suitable for non-parametric measurement of the strength and direction of the connection between two variables, measured at least on the ordinal scale (statistics.laerd.com/spss-tutorials/kendalls-tau-b-using-spss-statistics.php). The non-parametric nature of the variables was determined on the base of Shapiro Wilk normal distribution test. The value of the correlation coefficient ranges from -1 to +1 . A value of 0.1 to $0.3(-0.1$ to -0.3$)$ means a weak relationship, a value of 0.3 to 0.5 (-0.3 to -0.5$)$ is a moderate association and a value of 0.5 to 1.0 (-0.5 to -1.0$)$ indicates a very strong relationship (statistics.laerd.com/statistical-guides/pearson-correlation-coefficient-statistical-guide.php).

Linear regression was used to investigate the relationship between the business model and start-up performance (Tables 6, 7, 8, 9). Dependent variables are business model blocks that have quality (uniqueness, originality, level): 1 - local, 2 - national, 3 - central European, 4 - European, 5 - world and degree of development: 0 - 100 $\%$ (in tens of \%). An independent variable is the performance of a start-up that is measured as the number of users: 1 - none, 2 - several, 3 - several tens, 4 - several hundreds, 5 -several thousand, 6 - several ten thousand or more, 7 - more than a hundred thousand, number of paying users/customers: the scale is the same as for users and sales: 1 - none, $2-1-10000 €, 3-10001-50000 €, 4-50001-100000,5-100001-500000 €, 6-$ $500001-1000$ 000, 7 - more than $1000000 €$. Initially, a linear regression was applied to examine the relationship between individual independent variables (business model blocks) and performance indicators, and 


\section{ENTREPRENEURSHIP AND SUSTAINABILITY ISSUES}

ISSN 2345-0282 (online) http://jssidoi.org/jesi/

2021 Volume 8 Number 4 (June)

https://doi.org/10.9770/jesi.2021.8.4(2)

then multiple regression was applied to examine the relationship between the business model in aggregate (all independent variables together) and performance indicators.

The predominant method of discussion is to assess the excellence of new knowledge, respectively exceptional properties of start-ups and identification of paradoxes (interesting opposites or contradictions). Start-ups should deliver exceptional results that express in extraordinary quality and originality of their products and extraordinary growth. It is assumed that internal quality will turn into external quality.

\section{Research results}

\subsection{Elementary results/descriptive statistics}

Staffing (mean values are expressed in median).

Start-up leader, its founder is 33 years old. A significant majority of founders (86.7\%) have a university education of the second degree and several years as a rule employment practice $(56.7 \%)$ before establishing the start-up, but they lack the authentic business experience. The positive impact of education on business starting is also confirmed by a study of Hunady et al. (2018). In start-up there are working 5 employees who are 30 years old and are mostly university educated (83.3\%). The average lifetime of the surveyed start-ups by the end of 2018 is 4.9 years.

\section{Business idea}

Start-ups are making a business mainly in the industry of information and communication technologies (46.4\%). The rest of the start-ups operate in very diverse industries, e.g. industrial production, agriculture, other research, production of machinery, services, arts, entertainment, recreation and others.

Business ideas of studied start-ups can be divided into the following groups:

(a) collecting, pooling and producing specific information and fact sheets: Adwork, Venzeo, Muvity, Challengest, JobAngels, Luigi's Box; support of CV writing - KickResume, a search of human resources with specific skills and competencies for temporary use - SkillsMill, training in aviation regulations - alearn.aero,

b) linking things and various objects with information on their properties, operation and use: eDocu, Venzeo, Addwork, geolocation - Mapilary, food distribution monitoring - Orderlord,

(c) satisfying traditional needs in a simpler, faster and more convenient way: the cashier system for restaurants Storyous, invoicing - Sufio;

d) strengthening security, comfortable, simple and safe access to objects, buildings, apartments, cars: share.vi, personal security - Beesafe, human face identification and security - Matsuko,

e) supporting and developing ideas from other authors - Revolware,

(f) an original, as a rule, tangible product that meets an existing need in a new or more efficient way: Microveg, Greenway, Speekle, iBed Pro, Octago, RVMagnetics, GA Drilling, Quake resQ; not all ideas are based on complex and new technologies, e.g. new version of old service - Green Post.

Quoted business ideas are implemented as software applications (66\%) and products (33\%), which are predominantly tangible.

The circumstances and causes of the origin of an idea are reflected in the content of the business idea. Here are some examples:

- the original idea did not have sufficient business potential and has therefore undergone one or more changes (pivot), e.g. one app carries several similar services,

- the need for extensive and readily available information, e.g. about the facility being operated,

- demand for specialists, e.g. for human resource management, 


\section{ENTREPRENEURSHIP AND SUSTAINABILITY ISSUES}

ISSN 2345-0282 (online) http://jssidoi.org/jesi/

2021 Volume 8 Number 4 (June)

https://doi.org/10.9770/jesi.2021.8.4(2)

- establishing a sense of security, e.g. identification of faces and figures, warning before earthquake,

- confusing situation in some environment, e.g. real estate market, logistics of orders and deliveries of ready meals,

- personal experience of the entrepreneur, e.g. physical or mental discomfort; urgent lack of something, e.g. information, factory operators,

- the original services are lengthy, inconvenient, complicated, unautomated and not linked to other services or information systems.

The originality of the business idea is implicit, officially unconfirmed and considerably alleged (90\% of the sample). The founders' arguments in favour of the originality of the idea are diverse and based mainly on personal experience and subjective knowledge of the competition, which are often imperfect:

- industry knowledge and entrepreneurial experience confirming that the start-up under investigation is the only enterprise in the industry: eDocu, Octago,

- the first enterprise of its kind: Speekle,

- national originality, the only company in Slovakia: Revolware, Microveg,

- the originality of the idea is small, but the idea is implemented quickly and consistently: Greenway, Sli.do,

- considerable interest of foreign clients: Matsuko,

- very low price, 100 times lower than the competitive price: Quake resQ, or low price: Storyous,

- technological complexity, but without patent protection: iBed Pro,

- great adaptation to customer needs: Venzeo,

- there are several competitors, but startup has strong and loyal customers: Orderlord, Sli.do,

- the product resembles competing products but is different: Luigis Box,

- the product is complex and complicated or hybrid: KickResume, Mapilary, Green Post, KickResume. elearn.aero.

Explicit, officially confirmed originality, patent protection has been found only in start-ups share.vi, GADrilling, RVMagnetics (10\% of the examined sample). The degree of originality of the whole sample of business ideas measured on a five-point scale is 3.87, thus approaching originality at European level.

The development of the business idea was captured in the following phases: 1 - idea/ concept/research, 2 product development, 3 - product prototype/testing, 4 - first revenue, 5 - rising revenue. Most business ideas are situated in phase 4 (first revenue) or 5 (growing revenue), several ideas are in phase 3 (prototype completion and testing), the only idea is in phase 1 (idea and concept). The average development phase measured on a five-point scale is 4.1 , hence at the level of the first revenue. Phases 4 and 5 are characterized by continuous product innovation and improvement, so far independently and without exit. Sales revenues are growing, but not fast, rather slow, so start-ups usually do not attract strong investors. Start-ups are beginning to penetrate foreign markets and the challenge is not only to maintain growth but also to speed up significantly.

The start-up financing cycle is captured in the following phases: 1 - pre-seed capital (angel phase, idea, no product), 2 - start-up capital (seed phase, product developing and prototyping, market interest testing), 3 - capital for initial development and further growth (series $A / B$ phase, 1st, 2nd round, investment in a company that already has customers and generates revenue), 4 - development capital (3rd round, mezzanine capital), 5 - IPO (initial public offering). Most business ideas (44\%) are situated in phase 3 of the investment cycle (initial and growth capital). $13 \%$ of ideas are in phase 1 (pre-seed capital), $30 \%$ of ideas in phase 2 (start-up capital), $10 \%$ of ideas in stage 4 (development capital) and $3 \%$ of ideas in phase 5 (IPO). The average phase of the financing cycle, measured on a five point scale, is 2.6, hence between start-up capital and initial development capital. 


\section{ENTREPRENEURSHIP AND SUSTAINABILITY ISSUES}

ISSN 2345-0282 (online) http://jssidoi.org/jesi/

2021 Volume 8 Number 4 (June)

https://doi.org/10.9770/jesi.2021.8.4(2)

About $20 \%$ of start-ups are self-financing and want to do business with their own resources only. The rest relies on angel and venture investors who are expected to have business experience, advices and business contacts in addition to money. Start-ups do not receive any bank loans and grants, with the exception of GA Drilling, who received loans from the SZRB (Slovak guarantee and developing bank) and grants from EU programs. The Flemio accelerator provides pre-launch capital of 50,000 $€$ and the venture investor Neulogy grants a normal tranche of $200,000 €$. The process of raising external capital is lengthy. Domestic venture capital (VC) resources are very limited and institutional capital from foreign VC entrepreneurs and strong VC funds is almost unavailable. Start-ups invest mainly in prototype development and marketing. Marketing is a proxy term for advertising that serves to promote brand, product, and service awareness. One-off investments are not enough to cover the long term operation of a start-up and therefore have to be repeated in line with the product development. Sale revenue is also not enough to finance day-to-day operations and product development, so most start-ups need external investment support.

\section{Business model}

Customer value proposition was examined in the chain of need $\rightarrow$ value $\rightarrow$ minimum viable product (MVP). The example can be quoted: the chain of Quake resQ start-up. Need: increasing personal safety $\rightarrow$ value: measuring the size of seismic waves that a person has not yet captured with his senses $\rightarrow$ MVP: personal miniature device for wave detection. Satisfied needs are not significant news. The rate of their novelty was measured on the scale: 1 - exists long-term, 2 - exists short-term, 3 - just discovered/observed, 4 - just invented/created, and reached value of 1.46. Just discovered/observed and just invented/ created need occurred only in two cases. The following needs have been identified:

- find and acquire the missing human, material and information source, worker, staffer, information, data, e.g. a qualified employee for a permanent job or an expert for a temporary job, perform a professional work, find a real estate or property information (item, object, machine, etc.)

- get easy access into something or to something, e.g. car, hotel room, power source, natural resources,

- increase personal security,

- get an overview about the situation, e.g. movement of consignments, cars, the occurrence of negative events (waste stored in the wrong place), support for web search, getting feedback about a performance, facilitating and streamlining the entire food delivery process,

- promote a healthy lifestyle, e.g. exercising, eating, assistance at handicap,

- simplify and accelerate complicated processes,

- expand e-mobility.

The identified needs are met by the following values: time and cost savings; simplifying, facilitating processes and communication that were previously complex and labour intensive, inefficient, delayed; entirely new value that did not exist before.

The vehicle of values is a minimally viable product, which is an application on a smartphone or computer, very complex software, video record, training courses, various hardware, technical objects/equipment and technology. The degree of difference of the proposed products compared to similar products was measured on a scale: 1 common standard, 2 - moderate difference, 3 - greater difference, 4 - great difference, 5 - complete original, and reached level of 2.63. Only 17\% of the researched start-ups develop a completely original product. Quality or excellence of product measured on a five-point scale is 4.0, exactly at European level (53.3\% of examined startups). World-class quality, respectively excellence of product identified $27 \%$ of the researched start-ups. Developed products are finished at $76.2 \%$ on average.

Customer segments. Typical customers of the surveyed start-ups are larger to large enterprises (approximately 70\%), public administration institutions (approximately 10\%) and inhabitants (approximately 20\%). Customers 


\section{ENTREPRENEURSHIP AND SUSTAINABILITY ISSUES}

ISSN 2345-0282 (online) http://jssidoi.org/jesi/

2021 Volume 8 Number 4 (June)

https://doi.org/10.9770/jesi.2021.8.4(2)

are demanding, they have expectations and requirements measured on a five-point scale are on the level of 3.8, almost at European level. One third of start-ups have customers with world-class requirements. The average market segmentation, measured on a five-point scale, is on the level of 2.4 between a segmented market with several segments (50\% of the examined start-ups) and one segment. Start-ups identify and know their customers at $80 \%$ on average. On average, start-ups operate on the Central European market, but up to a third of them operate on the world market. They enter foreign markets on average from half a year to a year after the start of the sale of the product on the domestic market. Immediately after launching the product on the domestic market, 20\% of the researched start-ups enter the foreign market as well. Foreign branches have so far been established by $29 \%$ of the researched start-ups.

Customer relations are established and maintained at professional conferences and events attended by larger to large enterprises and public administration institutions. Customer relationships are also established and strengthened in face-to-face meetings and consultations, personal sales, social networks and satisfied customer references play an important role. An attractive product, high-end and original technology, a lower price, a unique distribution network (no other major competitors) and qualified sales also support relationships with customers. In customer relationships, personal assistance is predominant when the customer communicates directly with the seller, and extra personal assistance when the customer is assigned to a specific seller. The quality and uniqueness of these relationships, measured on a five-point scale, is on average at central European level (3.0). 13.3\% of the surveyed start-ups declare world-class relationships. Customer relations have so far reached on average $64.7 \%$ compared with the required level of $100 \%$.

Dominant distribution channels are custom website/FB online sales (53.3\% of the surveyed start-ups) and personal sales with own sellers (33.3\%), hence direct customer addressing, direct sales, personal delivery and product installation at the customer. Marginal distribution channels are conferences, lectures and partner stores. The most effective channel is personal sales, personal contact and relationship. Personal meetings are the most expensive, time and people consuming, but these channels are as functional as possible. The cheapest distribution channel is web/self-service shop. The quality and uniqueness of the distribution channel, measured on a five-point scale, is 2.8 on average, thus approaching the Central European level. Distribution channels are completed on average at $62 \%$.

Customers are used to waiting for the offer, they are more passive, and therefore personal addressing and servicing suit them. On the other hand, people are used to searching for information, commonly communicating through social networks, but the greatest benefit for them will be provided by personal product testing and personal experience. Ordering a service or product using an Internet application is a common standard in many industries and market segments and is also used by start-ups.

Personal selling is preferred because it does not need any intermediaries, and some start-ups do not want them. At a face-to-face meeting, the product is professionally demonstrated and explained, a start-up has got totally its business making under control and personal contact with the customer enables a better understanding of the customer's needs and his environment. The disadvantage is higher personnel costs, because it is necessary to send out an employee to the customers and possibly establish a subsidiary. Among the various forms of entry into the foreign market, direct export dominates $(77 \%)$. About one-third of the examined start-ups are not interested in how competing companies make sales and the other two-thirds report that their sales practices are the same or very similar.

Customer value proposition requires key resources, especially experts, developers and programmers. In addition, applied software, industry knowledge and technology mastering are needed. Significant resources are the hardworking and cohesive team, finance, technologies and the distribution network. Among these resources, there is a lack of quality and experienced people, top experts/specialists in the desired field, because they are expensive. 


\section{ENTREPRENEURSHIP AND SUSTAINABILITY ISSUES}

ISSN 2345-0282 (online) http://jssidoi.org/jesi/

2021 Volume 8 Number 4 (June)

https://doi.org/10.9770/jesi.2021.8.4(2)

There is also no money to pay for other quality staff, development, production and sales. The quality, uniqueness of resources is slightly above the Central European level (3.3) and resources are available in the range of $61.3 \%$ of the required final state (100\%). The sources were also evaluated according to their rarity and imitability (Table 1). The quantification of these features again confirms the central role of human resources in start-up business making.

Table 1. Rareness and imitability of business model resources

\begin{tabular}{|l|c|c|}
\hline \multicolumn{1}{|c|}{ Resources of business model } & Rareness of resources & Imitability of resources \\
\hline humans (know how, knowledge and experiences) & $\mathbf{4 , 0}$ & $\mathbf{4 , 1}$ \\
\hline humans (diligence and persistence) & 3,6 & 3,45 \\
\hline finance & 3,41 & 2,31 \\
\hline technologies & 2,38 & 2,79 \\
\hline venues & $\mathbf{1 , 6 2}$ & $\mathbf{1 , 5 5}$ \\
\hline
\end{tabular}

Scale of rareness: 1 (absolutely accessible, min. rare) - 5 (absolutely non-accessible, max. rare) Scale of imitability: 1 (absolutely imitable) - 5 (absolutely non-imitable)

Source: own field research

Offered value requires key processes, which are mainly product development, testing and development, sales, marketing (advertising), communication with customers and their servicing, and eventually further improvement of the product mainly based on customer requirements. The start-ups under investigation lack processes such as post-sales services, customer communication, care for customer during service usage, troubleshooting and answering to the complaints, various support services that require reinforcing the sales and recruitment of merchants. These processes are missing because some start-ups are only in the early stages of development or are limited by lack of finance, which is more often the reason. The quality, uniqueness of the processes is at the Central European level (3.0) and is developed at $67.2 \%$ of the required final state (100\%).

Key partners provide the missing resources, which are money for day-to-day operations and investments (35\% of partners); product know-how in the form of technology (18\% of partners), mentoring, software; know how about the market, entering the foreign market and feedback from customers. Partners rarely provide production realization of the developed product or access to the distribution network. Partners also provide some processes, such as the distribution of information about a start-up; advertising and promotion; sales, distribution of products and services at home and abroad (most common case); solution testing; software development and mediation of business contacts. About half of the examined start-ups do not state any activities that partners would undertake. Quality, excellence of partners is between the Central European and European levels (3.6) and partners are developed at $60.7 \%$ of the required final status $(100 \%)$.

Personnel costs (54\%) account for the largest share of the cost of key start-up resources, including the salaries of employees, especially those of highly qualified professionals. Among the key activities are the most expensive product development (29\%), advertising, promotion (20\%) and sales. Costs in relation to the resulting product prices, measured on a five point scale, are between high and low level $(2,9)$, as is the case for the ratio of fixed and variable costs $(3,1)$, whose relationship is almost balanced. The costs in relation to the relevant competitors are approximately the same (3.5). The cost structure will continue to change, having stabilized at $61.0 \%$ during the research period.

Revenue flows. Customers pay for the offered value/usefulness, although they formally pay for the purchase of an application, product or service. Formal payments are for sale of service (69\%), product (19\%), mediation of sale of service $(6 \%)$, sale of license $(3 \%)$ and other sale (3\%). Payment is made as a subscription/flat rate $(52 \%)$, on sale (19\%), after billing (26\%) and otherwise (3\%). The price of a product or service is determined as the sum of costs plus margin (37\%), according to market research $(21 \%)$, at the average market price (13\%) and intuitively 
ENTREPRENEURSHIP AND SUSTAINABILITY ISSUES

ISSN 2345-0282 (online) http://jssidoi.org/jesi/

2021 Volume 8 Number 4 (June)

https://doi.org/10.9770/jesi.2021.8.4(2)

(29\%). The premium price is required by $23.4 \%$, the cream price by $3.3 \%$, the introductory price by $40.0 \%$, the discount price by $10.0 \%$, and the linked price by $13.3 \%$ of start-ups.

Customer value proposition is often identified with a product, although the product is merely a material carrier of value/benefit. In fact, customers pay for instant and continuous access to information - $e D o c u$, access to various assets - share.vi, finding a scarce resource, e.g. talented, quality employee - SkillsMill, eliminating personal shortages - Speekle, finding a job - Challengest, provided advice - Revolware, saved time and lower costs - Green mail, more knowledge - Sli.do, simplifying and accelerating restaurant operation - Storyous, unique benefit brought by unique product feature - RVMagnetics, comfort, variability and originality of the product - iBed Pro.

In particular, the unfinished product is the cause of not generating income or insufficient volume of revenues. Start-ups are working on its development, or are not working sufficiently intensively, or are not working on development at all, because the money has run out and start-uppers are expending their efforts especially on raising more money. Other reasons for not generating sufficient revenue are the small number of paying users/customers and the underdeveloped market, which shows little interest in a product that is likely to overtake expectations and possibilities of customers. On average, surveyed start-ups have several tens to several hundreds of users who do not pay for a product or service, several to several tens of paying users (customers) who pay for a product and generate sales that cover approximately 75\% of start-ups costs. Profit earns 30\% of start-ups. However, the mean values of the economic indicators of the surveyed start-ups show (Table 2) that the average start-up does not earn profit and its gross margin is very modest.

Table 2. Mean values (median) of economy indicators of surveyed start-ups in 2017 year

\begin{tabular}{|l|r|}
\hline Indicator & \multicolumn{1}{|c|}{ Value } \\
\hline Sales/revenues (euro) & 76707 \\
\hline Profit (euro) & 0,0 \\
\hline Other earnings (euro) & 35 \\
\hline Assets (euro) & 107331 \\
\hline Equity (euro) & 15161 \\
\hline Total indebtedness (\%) & 64,5 \\
\hline Gross margin (\%) & 4,46 \\
\hline
\end{tabular}

Total indebtedness $=($ outside resources + time distinguishing $) /$ assets. It expresses in what extent a company finances its assets from outside resources.

Gross margin = value added/total sales. It expresses how many per cents remained to a company after payment of costs. Source: www.finstat.sk

It is clear from the summary (Table 3) that the best quality, most original and exceptional business model block is the customer value proposition delivering to the customer through the distribution channel, which is, however, the least quality block in addition to the revenue flows block. The most developed block is customers, but it is weakened by significantly less developed blocks of customer relationship development and distribution channels. The least developed block is revenue flows. 
Table 3. Summary assessment of business model blocks

\begin{tabular}{|c|c|c|c|}
\hline Blocks of business model & $\begin{array}{l}\text { Quality } \\
(1-5)\end{array}$ & Blocks of business model & $\begin{array}{c}\text { Degree of } \\
\text { development }(\%)\end{array}$ \\
\hline $\begin{array}{l}\text { Customer value } \\
\text { proposition/product }\end{array}$ & 4,0 & Customer segments & 80,34 \\
\hline Customer segments & 3,8 & $\begin{array}{l}\text { Customer value } \\
\text { proposition/product }\end{array}$ & 76,2 \\
\hline Key partners & 3,6 & Key activities & 67,2 \\
\hline Structure of costs & & Customer relationships & 64,7 \\
\hline Key resources & & Distribution channels & 61,9 \\
\hline Key activities & & Key resources & 61,3 \\
\hline Customer relationships & & Key partners & 60,7 \\
\hline Distribution channels & 2,8 & Structure of costs & 60,7 \\
\hline Revenues $^{*}$ & 2,43 & Revenues $^{* *}$ & $48,5 / 41,4$ \\
\hline
\end{tabular}

Block of revenues is measured on a 7-point scale, and therefore revenues in table are converted to a 5-point scale to make them comparable to other blocks.

Source: own field research

Positive experiences, strengths, achievements, right decisions of start-ups are very diverse, but the main and prevailing are the acquisition of large, respectively important clients, entry to foreign market, good identification of target customer, ability to recognize the right way of further development, diversification of customers, interest and increase of clients, personal sale, customer feedback.

Negative experiences, shortcomings, failures, mistakes are also very diverse, but the main and prevailing are a dysfunctional team and small funds, poor-quality human resources, respectively lack of quality people, especially specialists, slow development of the prototype due to lack of money, more agile competition and extremely difficult to attract an investment of several million euros.

Similarly, pivots (fundamental changes in the development of start-up) are very diverse, and therefore the unifying feature of their content cannot be found. Here are just a few examples:

- from a small number of large clients to a larger number of smaller clients - $e D o c u$,

- from e-lock, which is a platform for common access to doors, to access to various objects of the shared economy

- share.vi,

- from the extraction of geothermal energy (hot water wells) to deep wells for oil and gas - GADrilling,

- separation of support infrastructure from the product itself - Greenway,

- from creating 3D small figures to transmitting 3D image of real people (3D telepresence) - Matsuko,

- from an office building to an informal space, thus breaking free from the normal in-company environment Green Post,

- from an external distributor to own personal sales - Microveg,

- from self-service to explaining to the customer what the value of the product is - Sli.do,

- in addition to the original product for gastronomy/restaurants also a modification for large companies and other industries, e.g. banks and the public sector - Staffino.

Despite the content discrepancy of pivots, the start-ups under investigation are characterized by insufficient pivoting. There are few changes in addition to them at a slow frequency, generating new ideas is lengthy, respectively start-ups have an aversion to discard old ideas and lack a steady inclination to enthusiastic and tireless search for new ideas. If there was a pivot, it wasn't too much of a change. 


\subsection{Relational results/Correlations}

Correlation analysis examines the tightness of dependency between business model blocks that are quantified by the degree of quality and the degree of development. The dominant block in the business model (Table 4), whose blocks are expressed in terms of quality, is the product/customer value proposition because it shows the most relevant/close relationships with the other blocks of the model. Key partners and cost structure, in turn, show a minimum of close relationships. The key partners and cost structure are the dominant blocks in the business model (Table 5), which blocks are expressed by the degree of development. Customers play a weaker role in this case. The business model is very consistent in both ways of expression, but the model measured by the degree of development shows more integrity. The ascertained consistency creates good prerequisites not only for regression analysis but also for the practical functioning of the model.

Table 4. Correlation between blocks (quality) of business model. Kendall's tau B test.

\begin{tabular}{|c|c|c|c|c|c|c|c|c|c|}
\hline Quality of blocks & $\begin{array}{c}\text { CVP/ } \\
\text { Product }\end{array}$ & $\begin{array}{l}\text { Customer } \\
\text { segments }\end{array}$ & $\begin{array}{l}\text { Customer } \\
\text { relationships }\end{array}$ & $\begin{array}{l}\text { Distribution } \\
\text { channels }\end{array}$ & $\begin{array}{c}\text { Key } \\
\text { resources }\end{array}$ & $\begin{array}{c}\text { Key } \\
\text { activities }\end{array}$ & $\begin{array}{c}\text { Key } \\
\text { partners }\end{array}$ & $\begin{array}{c}\text { Cost } \\
\text { structure }\end{array}$ & Revenues \\
\hline $\begin{array}{l}\text { Customer value } \\
\text { proposition/ } \\
\text { product }\end{array}$ & 1,000 & & & & & & & & \\
\hline $\begin{array}{l}\text { Customer } \\
\text { segments }\end{array}$ & $0,608 * *$ & 1,000 & & & & & & & \\
\hline $\begin{array}{l}\text { Customer } \\
\text { relationships }\end{array}$ & $0,384 *$ & $0, \mathbf{4 8 9} * *$ & 1,000 & & & & & & \\
\hline $\begin{array}{l}\text { Distribution } \\
\text { channels }\end{array}$ & $\mathbf{0 , 3 5 8 *}$ & 0,276 & $0,395 *$ & 1,000 & & & & & \\
\hline Key resources & $0,403 *$ & $\mathbf{0 , 3 8 5 *}$ & 0,309* & 0,289 & 1,000 & & & & \\
\hline Key activities & 0,117 & 0,250 & 0,255 & $0,343^{*}$ & $0,553 * *$ & 1,000 & & & \\
\hline Key partners & $0,330 *$ & 0,298 & 0,247 & 0,149 & $0,553 * *$ & 0,219 & 1,000 & & \\
\hline Cost structure & 0,021 & 0,031 & $-0,228$ & $-0,325^{*}$ & 0,231 & 0,009 & 0,209 & 1,000 & \\
\hline Revenues & $-0,097$ & 0,023 & 0,177 & 0,100 & 0,041 & 0,222 & 0,238 & $-0,126$ & 1,000 \\
\hline
\end{tabular}


Table 5. Correlation between blocks (degree of development) of the business model. Kendall's tau B test.

\begin{tabular}{|c|c|c|c|c|c|c|c|c|c|}
\hline $\begin{array}{l}\text { Degree of blocks } \\
\text { development }\end{array}$ & $\begin{array}{c}\text { CVP/ } \\
\text { Product }\end{array}$ & $\begin{array}{l}\text { Customer } \\
\text { segments }\end{array}$ & $\begin{array}{l}\text { Customer } \\
\text { relationships }\end{array}$ & $\begin{array}{l}\text { Distribution } \\
\text { channels }\end{array}$ & $\begin{array}{c}\text { Key } \\
\text { resources }\end{array}$ & $\begin{array}{c}\text { Key } \\
\text { activities }\end{array}$ & $\begin{array}{c}\text { Key } \\
\text { partners }\end{array}$ & $\begin{array}{c}\text { Cost } \\
\text { structure }\end{array}$ & Revenues \\
\hline $\begin{array}{l}\text { Customer value } \\
\text { proposition/ } \\
\text { product }\end{array}$ & 1,000 & & & & & & & & \\
\hline $\begin{array}{l}\text { Customer } \\
\text { segments }\end{array}$ & 0,165 & 1,000 & & & & & & & \\
\hline $\begin{array}{l}\text { Customer } \\
\text { relationships }\end{array}$ & $0,311 *$ & $0,385^{* *}$ & 1,000 & & & & & & \\
\hline $\begin{array}{l}\text { Distribution } \\
\text { channels }\end{array}$ & $0,376^{* * *}$ & 0,246 & $0,541 * *$ & 1,000 & & & & & \\
\hline Key resources & $\mathbf{0 , 3 3 5} * *$ & $0,314 *$ & $0,422 * *$ & $0,437 * *$ & 1,000 & & & & \\
\hline Key activities & $0,472 * *$ & $0,331 *$ & $0,540 * *$ & $0,420 * *$ & $0,485^{* *} *$ & 1,000 & & & \\
\hline Key partners & $0,374 * *$ & $0,567 * *$ & $0,368 * *$ & $0,353 * *$ & $0,455 * *$ & $0,519 * *$ & 1,000 & & \\
\hline Cost structure & $0,379 * *$ & $0,297 *$ & $0,408 * *$ & $0,455 * *$ & $0,590 * *$ & $0,461 * *$ & $0,374 * *$ & 1,000 & \\
\hline Revenues & 0,361* & $0,435 * *$ & $0,438 * *$ & $0,386 * *$ & $0,629 * *$ & $0,498 * *$ & $0,427 * *$ & $0,618 * *$ & 1,000 \\
\hline
\end{tabular}

Of the selected attributes (Table 6), the business idea development/business idea development phase, the investment cycle/financing development phase and the type of territorial market/from local to international expansion have a statistically significant impact on start-up performance. This impact is also reflected in the relatively high values of the $\mathrm{B}$ and $\mathrm{R}$ Square coefficients. The other attributes examined are not statistically relevant.

Table 6. Relationship (linear regression) between selected attributes of start-up and its performance

\begin{tabular}{|l|l|c|c|c|}
\hline \multirow{4}{*}{ Attribute } & \multirow{2}{*}{ Statistical indicators } & \multicolumn{2}{|c|}{ Performance of start-up } \\
\cline { 3 - 5 } & & $\begin{array}{c}\text { Number of } \\
\text { users }\end{array}$ & $\begin{array}{c}\text { Number of } \\
\text { paying users }\end{array}$ & Sales \\
\hline \multirow{5}{*}{ Age of founder } & Unstandardized Coefficients - B & $-0,035$ & $-0,016$ & 0,105 \\
\cline { 2 - 5 } & Unstandardized Coefficients - Std. Error & 0,042 & 0,045 & 0,043 \\
\cline { 2 - 5 } & R Square & 0,027 & 0,005 & 0,179 \\
\cline { 2 - 5 } & Sig. & 0,405 & 0,718 & $\mathbf{0 , 0 2 2} *$ \\
\hline \multirow{5}{*}{ Age of team } & Unstandardized Coefficients - B & $-0,044$ & $-0,061$ & 0,173 \\
\cline { 2 - 5 } & Unstandardized Coefficients - Std. Error & 0,075 & 0,073 & 0,074 \\
\cline { 2 - 5 } & R Square & 0,013 & 0,028 & 0,168 \\
\cline { 2 - 5 } & Sig. & 0,560 & 0,405 & $\mathbf{0 , 0 2 7} *$ \\
\hline \multirow{3}{*}{ Originality of } & Unstandardized Coefficients - B & $-0,033$ & $-0,031$ & $-0,026$ \\
\cline { 2 - 5 } & Unstandardized Coefficients - Std. Error & 0,057 & 0,058 & 0,066 \\
\cline { 2 - 5 } & R Square & 0,012 & 0,011 & 0,005 \\
\cline { 2 - 5 } & Sig. & 0,570 & 0,589 & 0,701 \\
\hline \multirow{3}{*}{$\begin{array}{l}\text { Development } \\
\text { phase - idea }\end{array}$} & Unstandardized Coefficients - B & 0,870 & 0,972 & 0,728 \\
\cline { 2 - 5 } & Unstandardized Coefficients - Std. Error & 0,265 & 0,256 & 0,330 \\
\cline { 2 - 5 } & R Square & 0,285 & 0,357 & 0,148 \\
\cline { 2 - 5 } & Sig. & $\mathbf{0 , 0 0 3} *$ & $\mathbf{0 , 0 0 1 *}$ & $\mathbf{0 , 0 3 6}$ \\
\hline Development & Unstandardized Coefficients - B & 0,453 & 0,906 & 0,933 \\
\hline
\end{tabular}


ENTREPRENEURSHIP AND SUSTAINABILITY ISSUES

ISSN 2345-0282 (online) http://jssidoi.org/jesi/

2021 Volume 8 Number 4 (June)

https://doi.org/10.9770/jesi.2021.8.4(2)

\begin{tabular}{|c|c|c|c|c|}
\hline \multirow{3}{*}{$\begin{array}{l}\text { phase - } \\
\text { financing }\end{array}$} & Unstandardized Coefficients - Std. Error & 0,330 & 0,299 & 0,336 \\
\hline & R Square & 0,065 & 0,261 & 0,216 \\
\hline & Sig. & 0,181 & $0,006 *$ & $0,010 *$ \\
\hline \multirow{4}{*}{$\begin{array}{l}\text { Rate of product } \\
\text { difference }\end{array}$} & Unstandardized Coefficients - B & 0,030 & 0,105 & 0,233 \\
\hline & Unstandardized Coefficients - Std. Error & 0,357 & 0,380 & 0,396 \\
\hline & R Square & 0,000 & 0,003 & 0,013 \\
\hline & Sig. & 0,933 & 0,784 & 0,560 \\
\hline \multirow{4}{*}{$\begin{array}{l}\text { Kind of } \\
\text { territorial } \\
\text { market }\end{array}$} & Unstandardized Coefficients - B & 0,442 & 0,481 & 0,637 \\
\hline & Unstandardized Coefficients - Std. Error & 0,182 & 0,184 & 0,198 \\
\hline & R Square & 0,180 & 0,208 & 0,270 \\
\hline & Sig. & $0,022 *$ & $0,015 *$ & $0,003 *$ \\
\hline
\end{tabular}

Among the blocks expressed in quality (Table 7), customer relations, distribution channels, key resources and key activities are influencing start-up performance. This effect is also confirmed by the relevant values of B and $\mathrm{R}$ Square coefficients. However, none of the blocks affects performance expressed in revenues. Almost all blocks expressed by the degree of development (Table 8) have a statistically significant impact on start-up performance measured by the number of users and the number of paying users. Revenue is only affected by customer relationships, key resources, key activities and cost structure. However, the B and R Square coefficients are smaller than in the case of the qualitatively measured model. Key partners have the least impact.

Table 7. Relation (simple linear regression) between the quality of individual blocks and the performance of the start-up

\begin{tabular}{|c|c|c|c|c|}
\hline $\begin{array}{l}\text { Quality of } \\
\text { blocks }\end{array}$ & Statistical indicators & $\begin{array}{c}\text { Number of } \\
\text { users }\end{array}$ & $\begin{array}{l}\text { Number of } \\
\text { paying users }\end{array}$ & Sales \\
\hline \multirow{4}{*}{$\begin{array}{l}\text { Customer } \\
\text { value } \\
\text { proposition/ } \\
\text { product }\end{array}$} & Unstandardized Coefficients - B & $-0,220$ & $-0,143$ & $-0,298$ \\
\hline & Unstandardized Coefficients - Std. Error & 0,039 & 0,445 & 0,465 \\
\hline & R Square & 0,011 & 0,004 & 0,015 \\
\hline & Sig. & 0,581 & 0,750 & 0,528 \\
\hline \multirow{4}{*}{$\begin{array}{l}\text { Customer } \\
\text { segments }\end{array}$} & Unstandardized Coefficients - B & 0,137 & 0,329 & 0,105 \\
\hline & Unstandardized Coefficients - Std. Error & 0,283 & 0,316 & 0,339 \\
\hline & R Square & 0,009 & 0,040 & 0,004 \\
\hline & Sig. & 0,632 & 0,307 & 0,760 \\
\hline \multirow{4}{*}{$\begin{array}{l}\text { Customer } \\
\text { relationships }\end{array}$} & Unstandardized Coefficients - B & 0,475 & 0,502 & 0,361 \\
\hline & Unstandardized Coefficients - Std. Error & 0,228 & 0,262 & 0,309 \\
\hline & R Square & 0,149 & 0,133 & 0,054 \\
\hline & Sig. & $0,047 *$ & 0,067 & 0,254 \\
\hline \multirow{4}{*}{$\begin{array}{l}\text { Distribution } \\
\text { channels }\end{array}$} & Unstandardized Coefficients - B & 0,462 & 0,491 & 0,175 \\
\hline & Unstandardized Coefficients - Std. Error & 0,258 & 0,262 & 0,318 \\
\hline & R Square & 0,106 & 0,119 & 0,012 \\
\hline & Sig. & $\mathbf{0 , 0 8 5}$ & $\mathbf{0 , 0 7 3}$ & 0,586 \\
\hline \multirow{4}{*}{$\begin{array}{l}\text { Key } \\
\text { resources }\end{array}$} & Unstandardized Coefficients - B & 0,359 & 0,488 & 0,059 \\
\hline & Unstandardized Coefficients - Std. Error & 0,218 & 0,216 & 0,278 \\
\hline & R Square & 0,091 & 0,164 & 0,002 \\
\hline & Sig. & 0,112 & $\mathbf{0 , 0 3 3} *$ & 0,835 \\
\hline \multirow{4}{*}{$\begin{array}{l}\text { Key } \\
\text { activities }\end{array}$} & Unstandardized Coefficients - B & 0,452 & 0,720 & 0,340 \\
\hline & Unstandardized Coefficients - Std. Error & 0,216 & 0,199 & 0,270 \\
\hline & R Square & 0,140 & 0,335 & 0,057 \\
\hline & Sig. & $0,046 *$ & $0,001 *$ & 0,220 \\
\hline \multirow{3}{*}{ Key partners } & Unstandardized Coefficients - B & 0,511 & 0,552 & 0,509 \\
\hline & Unstandardized Coefficients - Std. Error & 0,336 & 0,329 & 0,404 \\
\hline & R Square & 0,082 & 0,098 & 0,060 \\
\hline
\end{tabular}




\section{ENTREPRENEURSHIP AND SUSTAINABILITY ISSUES}

ISSN 2345-0282 (online) http://jssidoi.org/jesi/

2021 Volume 8 Number 4 (June)

https://doi.org/10.9770/jesi.2021.8.4(2)

\begin{tabular}{|l|l|c|c|c|}
\hline & Sig. & 0,140 & 0,105 & 0,220 \\
\hline \multirow{4}{*}{$\begin{array}{l}\text { Cost } \\
\text { structure }\end{array}$} & Unstandardized Coefficients - B & $-0,030$ & $-0,152$ & $-0,376$ \\
\cline { 2 - 5 } & Unstandardized Coefficients - Std. Error & 0,368 & 0,378 & 0,398 \\
\cline { 2 - 5 } & R Square & 0,000 & 0,006 & 0,033 \\
\cline { 2 - 5 } & Sig. & 0,936 & 0,691 & 0,353 \\
\hline
\end{tabular}

Table 8. Relation (simple linear regression) between the degree of development of individual blocks and the performance of start-up

\begin{tabular}{|c|c|c|c|c|}
\hline $\begin{array}{l}\text { Degree of } \\
\text { blocks } \\
\text { development }\end{array}$ & Statistical indicators & $\begin{array}{c}\text { Number of } \\
\text { users }\end{array}$ & $\begin{array}{c}\text { Number of } \\
\text { paying users }\end{array}$ & Sales \\
\hline \multirow{4}{*}{$\begin{array}{l}\text { Customer } \\
\text { value } \\
\text { proposition/ } \\
\text { product }\end{array}$} & Unstandardized Coefficients - B & 0,025 & 0,034 & 0,027 \\
\hline & Unstandardized Coefficients - Std. Error & 0,012 & 0,012 & 0,015 \\
\hline & R Square & 0,138 & 0,236 & 0,107 \\
\hline & Sig. & $0,048 *$ & $0,009 *$ & 0,089 \\
\hline \multirow{4}{*}{$\begin{array}{l}\text { Customer } \\
\text { segments }\end{array}$} & Unstandardized Coefficients - B & 0,029 & 0,035 & 0,013 \\
\hline & Unstandardized Coefficients - Std. Error & 0,014 & 0,013 & 0,018 \\
\hline & R Square & 0,152 & 0,219 & 0,020 \\
\hline & Sig. & $0,040 *$ & $0,014 *$ & 0,477 \\
\hline \multirow{4}{*}{$\begin{array}{l}\text { Customer } \\
\text { relationships }\end{array}$} & Unstandardized Coefficients - B & 0,034 & 0,033 & 0,026 \\
\hline & Unstandardized Coefficients - Std. Error & 0,009 & 0,009 & 0,012 \\
\hline & R Square & 0,349 & 0,321 & 0,151 \\
\hline & Sig. & $0,001 *$ & $0,002 *$ & $0,041 *$ \\
\hline \multirow{4}{*}{$\begin{array}{l}\text { Distribution } \\
\text { channels }\end{array}$} & Unstandardized Coefficients - B & 0,026 & 0,029 & 0,019 \\
\hline & Unstandardized Coefficients - Std. Error & 0,011 & 0,010 & 0,013 \\
\hline & R Square & 0,182 & 0,232 & 0,077 \\
\hline & Sig. & 0,024* & $0,009 *$ & 0,161 \\
\hline \multirow{4}{*}{ Key resources } & Unstandardized Coefficients - B & 0,047 & 0,058 & 0,042 \\
\hline & Unstandardized Coefficients - Std. Error & 0,012 & 0,010 & 0,016 \\
\hline & R Square & 0,365 & 0,571 & 0,205 \\
\hline & Sig. & 0,001* & $0,000 *$ & $0,016 *$ \\
\hline \multirow{4}{*}{ Key activities } & Unstandardized Coefficients - B & 0,031 & 0,039 & 0,035 \\
\hline & Unstandardized Coefficients - Std. Error & 0,012 & 0,011 & 0,015 \\
\hline & R Square & 0,198 & 0,358 & 0,182 \\
\hline & Sig. & 0,018* & $0,001 *$ & $0,027^{*}$ \\
\hline \multirow{4}{*}{ Key partners } & Unstandardized Coefficients - B & 0,022 & 0,031 & 0,022 \\
\hline & Unstandardized Coefficients - Std. Error & 0,011 & 0,010 & 0,013 \\
\hline & R Square & 0,129 & 0,294 & 0,099 \\
\hline & Sig. & 0,061 & $\mathbf{0 , 0 0 3} *$ & 0,109 \\
\hline \multirow{4}{*}{ Cost structure } & Unstandardized Coefficients - B & 0,042 & 0,050 & 0,051 \\
\hline & Unstandardized Coefficients - Std. Error & 0,011 & 0,010 & 0,014 \\
\hline & R Square & 0,340 & 0,514 & 0,337 \\
\hline & Sig. & $0,001 *$ & $0,000 *$ & $0,002 *$ \\
\hline
\end{tabular}

Table 9 records the results of multiple regression between a business model that is perceived as a summary of blocks, and the performance of a start-up. Thus, the relationship between the whole model, not the individual blocks, and the start-up performance is examined. The purpose of such an examination is to distinguish the individual impact of blocks and the aggregate impact of the model on start-up performance. The impact of the model on performance is statistically significant except for the impact of a qualitatively measured model on revenues. R Square and Adjusted R Square values measured for multiple regression are higher than for single 
regression, and performance of start-up is induced from $57.1 \%$ to $75.2 \%$ by the quality and degree of business model development, while the degree of development explains this impact somewhat more than quality of model. However, the values of the B coefficients are evidently lower for the model measured by the degree of development than for the model measured by quality.

Table 9. Relationship (multiple linear regression) between the quality and degree of development of the entire business model and the performance of the start-up

\begin{tabular}{|l|c|c|c|c|c|c|}
\hline \multirow{3}{*}{ Blocks } & \multicolumn{3}{|c|}{$\begin{array}{c}\text { Impact of blocks quality on the } \\
\text { performance }\end{array}$} & \multicolumn{2}{c|}{$\begin{array}{c}\text { Impact of blocks development degree on } \\
\text { the performance }\end{array}$} \\
\cline { 2 - 7 } & $\begin{array}{c}\text { Number of } \\
\text { users }\end{array}$ & $\begin{array}{c}\text { Number of } \\
\text { paying users }\end{array}$ & Sales & $\begin{array}{c}\text { Number of } \\
\text { users }\end{array}$ & $\begin{array}{c}\text { Number of } \\
\text { paying users }\end{array}$ & Sales \\
\hline \multirow{2}{*}{$\begin{array}{l}\text { Customer value } \\
\text { proposition/ } \\
\text { product }\end{array}$} & $-0,924$ & $-1,091$ & $-1,577$ & 0,009 & 0,008 & 0,014 \\
\hline \multirow{3}{*}{ Customer segments } & $(0,580)$ & $(0,601)$ & $(0,880)$ & $(0,014)$ & $(0,012)$ & $(0,018)$ \\
\hline \multirow{3}{*}{ Customer relationships } & $-0,181$ & 0,157 & 0,434 & 0,016 & 0,010 & $-0,044$ \\
\cline { 2 - 7 } & $(0,346)$ & $(0,393)$ & $(0,577)$ & $(0,024)$ & $(0,019)$ & $(0,029)$ \\
\cline { 2 - 7 } & 0,433 & 0,206 & 0,520 & 0,032 & 0,010 & 0,036 \\
\hline \multirow{3}{*}{ Distribution channels } & $(0,258)$ & $(0,300)$ & $(0,429)$ & $(0,015)$ & $(0,013)$ & $(0,019)$ \\
\hline \multirow{3}{*}{ Key resources } & 0,843 & 0,256 & 0,145 & $-0,016$ & $-0,010$ & $-0,029$ \\
\hline \multirow{3}{*}{ Key activities } & $(0,299)$ & $(0,316)$ & $(0,453)$ & $(0,015)$ & $(0,012)$ & $(0,018)$ \\
\hline \multirow{3}{*}{ Key partners } & 0,154 & 0,114 & $-0,595$ & 0,052 & 0,054 & 0,023 \\
\hline \multirow{3}{*}{ Cost structure } & $(0,376)$ & $(0,435)$ & $(0,625)$ & $(0,023)$ & $(0,017)$ & $(0,026)$ \\
\hline R & $-0,063$ & 0,485 & 0,790 & 0,003 & 0,017 & 0,010 \\
\hline R Square & $(0,317)$ & $(0,351)$ & $(0,512)$ & $(0,017)$ & $(0,014)$ & $(0,021)$ \\
\hline Adjusted R Square & 0,274 & 0,493 & 0,529 & $-0,043$ & $-0,021$ & $-0,016$ \\
\hline Std. Error of the Estimate & $(0,378)$ & $(0,397)$ & $(0,578)$ & $(0,018)$ & $(0,015)$ & $(0,022)$ \\
\hline Sig. & $-0,161$ & $-0,256$ & $-0,113$ & 0,011 & 0,009 & 0,048 \\
\cline { 2 - 7 } & $(0,431)$ & $(0,442)$ & $(0,636)$ & $(0,018)$ & $(0,015)$ & $(0,022)$ \\
\cline { 2 - 7 } & 0,77 & 0,756 & 0,656 & 0,802 & 0,867 & 0,786 \\
\hline & $\mathbf{0 , 5 9 4}$ & $\mathbf{0 , 5 7 1}$ & 0,431 & $\mathbf{0 , 6 4 3}$ & $\mathbf{0 , 7 5 2}$ & $\mathbf{0 , 6 1 7}$ \\
\hline & 0,402 & 0,37 & 0,146 & 0,475 & 0,635 & 0,426 \\
\hline
\end{tabular}

\section{Discussion}

\section{Personal background}

Personnel background is made up of people with the same education as in the previous research (Slávik, 2019), but the founders are getting older and approaching with their age the founders of start-ups in developed countries. Education and experience are mainly used for product development, they are reflected less (little?) in more sophisticated market entry, customer acquisition and monetization of business efforts. Start-ups are small entities due to their age, they remain micro enterprises with very limited work and intellectual capacity, which fundamentally determines the speed of development and growth of business.

\section{Business idea and start-up development cycle}

Information and communication technologies dominate the business ideas. Software applications are easier to "manufacture" and sell than tangible products, they do not need a manufacturing base and many collaborators, and are in line with technology trends, lifestyles and the spirit of the times. The causes of business idea are trivial, e.g. something is missing or not working, some process is lengthy or inconvenient, but an imaginative entrepreneur sees more sophisticated content in some imperfection or deficiency e.g. lack of specific information or confusing 


\section{ENTREPRENEURSHIP AND SUSTAINABILITY ISSUES}

ISSN 2345-0282 (online) http://jssidoi.org/jesi/

2021 Volume 8 Number 4 (June)

https://doi.org/10.9770/jesi.2021.8.4(2)

and disordered information. The conditions for creating an idea are mainly personal experience and sensitive observation of the surroundings, but is it enough for an original business idea? Often declared exceptional originality of the business idea is a fundamental problem of the researched start-ups. Unconfirmed assumptions, impressions, and various subjective arguments prevail, which cause later failure and disappointment. The notion of self-exceptionality is usually the consequence of insufficient knowledge of the idea, theme, industry and underestimation or disregard of real competition on a wider European and global scale. The key influence of quality business orientation on the sustainability of a start-up is also confirmed by the results of research by Voinea et al. (2019).

It takes too long to develop a business idea. Successful start-ups in the world will show their viability within three years from their establishment and then scale or exit. In almost five years of existence, the examined start-ups have reached the beginning of phase 4 of the business idea development (4.1: first revenues) and show no signs of exponential growth. In the funding cycle, they arrived between phases 2 and 3 (2.6: between start-up capital and initial and development capital). There is a clear difference in the progress of business development and investment cycle. The founders lack big money of several million euros and investors do not trust the underdeveloped product, which is not confirmed by market interest.

\section{Business model}

The customer value proposition is situated in the middle of the chain: missing human, material and information resource (need) $\rightarrow$ simplification, facilitation of processes and communication needed to procure resources that were previously complex and labour intensive (value) $\rightarrow$ application (MVP). Satisfied needs are not revolutionary, respectively they are no revealing blue oceans, values are usually to simplify and facilitate access to information or a tangible product, while minimum viable product is at European level, which paradoxically surpasses the relative routine of satisfied needs and values offered.

Customer segments are represented by demanding customers at European level, although paradoxically start-ups are more orientated to the domestic market, which is very small (5.5 million inhabitants), business customers (B2B) dominate significantly on the served segments and start-ups have little bargaining power toward them. Eventually, start-ups serve one or a few segments, what is corresponding to their capabilities.

Customer relations are dominated by personal assistance, which is very demanding on human resources. However, start-up has paradoxically a very limited amount of staff.

Distribution channels are realized through their own website, personal contacts and relationships, but they are laborious and costly. Start-ups have aversion to intermediaries and therefore carry out direct export. Again, paradoxically, start-uppers want to sell almost everything themselves and without foreign help.

Key resources are also marked by a paradox when the founder has an idea, but he cannot develop it without experts and specialists because they are expensive, very rare and difficult to imitate/substitute. Financial resources lack, but there is absence of bootstraping, and paradoxically, an idea/product that is declared as a world original does not attract investors and their money.

Paradoxically, key processes do not include advanced customer service processes, although start-ups are in phase 4 of the business cycle (first revenues). The lagging behind in the development of not only this block of business model is probably a characteristic feature of start-ups.

Key partners are limited only to cooperation in distribution (dealers) and procurement of money (investors). Half of the start-ups have no partners, with existing partners having a higher than lower quality (3.6) and paradoxically a lower than higher level of development $(60.7 \%)$. 


\section{ENTREPRENEURSHIP AND SUSTAINABILITY ISSUES}

ISSN 2345-0282 (online) http://jssidoi.org/jesi/

2021 Volume 8 Number 4 (June)

https://doi.org/10.9770/jesi.2021.8.4(2)

Costs and their indicators are around the middle, hence costs in relation to the final prices of production, prices of relevant competitors and the ratio between fixed and variable costs. It is a manifestation of caution, risk aversion and a tendency towards mediocrity, which is a paradox of the notion about excellence and innovativeness of startup. The research of Hudáková et al. (2019) also draws attention to the irreplaceable role of partners in the sustainable development of start-ups.

Revenue flows are insufficient due to start-up age. Start-ups have few users, even fewer customers, and revenues do not cover costs. The average start-up is at a loss and has a thin gross margin. Monetization imitate common practice, no compelling innovations can be seen. Again, there is a paradox when a relatively high quality and developed value offer is not transformed into revenues.

The summary assessment of the units reveals several paradoxes between the quality and the degree of development of some units:

- partners and cost structure are more quality blocks but less developed,

- processes, customer relationships and distribution are of lower quality but more developed, but the differences are small,

- the value offered and customers are highly prominent, distribution, customer relations (quality), partners and costs (degree of development) are insufficient, therefore implementation and sales are lagging behind and revenue flows are consequently lagging behind.

Start-ups are not fast enough in their development. They are weakened by the lack of progress due to the lack of financial and human resources. Their success depends on winning a new customer and their failure is caused the lack of high-quality, highly professional human resources, stagnant teamwork and lack of big money. Start-ups pivot less than necessary. However, the experimental nature of start-up requires this. Concentrating on one idea without major changes over a longer period is also one of the reasons for lengthy growth and failure.

\section{Relations/correlations}

Among the business model blocks that are measured by quality degree (Table 4), there is a relatively broad occurrence of strong correlation, but the dominant block of correlation table 4 and evaluating table 3 , which is the customer value proposition/product, has paradoxically negligible impact on the final performance (Table 7, 8, 9). Key business partners and cost structure dominate among the business model blocks which are measured by the degree of development (Table 5), but again their impact on performance (Table 7, 8, 9) is insignificant. Paradoxically, strong relationships of an individual block do not result in an individual significant impact on performance, or they do not succeed to convert into a contribution to the performance. However, the business model is quite consistent overall and this is reflected in its overall impact on start-up performance (Table 9).

The strong correlation of key partners appears to be a manifestation of the need for partnership/external cooperation across all blocks of business model. It is a confirmation of the necessity of partnership, although startups do not like to admit it. They want to maintain independence, but which is an obstacle to acceleration, scaling and exponential growth. The confirmation of an effort for an independence is also the lower level of development of partners $(60.7 \%)$.

\section{Relations/regressions}

The impact of start-up development measured by business idea development, investment and territorial expansion has been demonstrated (Table 6). This impact was expected and is in line with the logic of building a company. Noteworthy is the statistically insignificant impact of the team founder's age, originality of the idea, and the degree of product differentiation, since the founder's age (Garaj, 2015) is considered an important investment criterion and originality and differentiation are considered essential sources of competitive advantage. 


\section{ENTREPRENEURSHIP AND SUSTAINABILITY ISSUES}

ISSN 2345-0282 (online) http://jssidoi.org/jesi/

2021 Volume 8 Number 4 (June)

https://doi.org/10.9770/jesi.2021.8.4(2)

There is an apparent difference between the impact of block quality and the impact of block development on startup performance (Tables 7,8). Block development, its completion is more efficient than block quality. The quality impact is obviously determined by the block implementation and not vice versa. However, influential blocks (there are fewer) of a qualitatively measured model have a greater effect on performance than influential blocks (there are more) of a model measured by the degree of development. What, then, is a driver of performance? The only conclusion is that the model has some impact on the performance measured by the number of users and the number of customers, and does not have a statistically significant impact on revenues. The discrepancy between the impact of the model on non-financial (number of users and customers) and financial (sales) indicators of performance is evident. The weak conversion of users and customers to revenue is also likely to be affected by an unfinished model and other factors, e.g. pricing, founder experience, market size, money for development.

It can be assumed that multiple correlation expresses the model's impact on performance more realistic than simple correlation, because the model practically operates as an aggregate of cooperating blocks and not as a collection of individually and independently functioning blocks. On the other hand, the influence of the individual blocks may not excel. The development-measured model explains more (R Square) the impact on start-up performance than the quality-measured model, but the contributions of its blocks (B coefficients) are less than those of the quality-measured model blocks. The higher functionality (higher degree of development) of the model contributes slightly more to the performance than its overall higher quality. Meanwhile, a more functional model has a slightly greater impact on performance than a more quality model.

The goals of the research were met and the acquired knowledge contributes to the improvement of knowledge about the personnel background of the startup, the origin of the business idea, the structure of the business model and its impact on business performance. Perhaps the main and summarizing knowledge is that start-ups are imperfect companies with an exclusive and at the same time limited exceptionality, which they must supplement with complementary assets.

\section{Conclusion}

The start-ups under investigation are slow in their development and do not succeed to monetize the results of their efforts. Given their very limited own resources, they have little partnerships, whereby they have an aversion to some kinds of external cooperation, which they inevitably have to reveal its inside. Even though start-ups come with innovations, they are conservative at the same time because they make small number of pivots. They do not want to change their business concept often and significantly, although it does not bring the expected results. They are full of different paradoxes that are the consequence of their smallness. The business model is not innovative, the level of blocks is unbalanced and is reflected in underperformance. Start-ups concentrate on the block of customer value proposition, both qualitative and developmental lagging of other blocks is obvious and that is why the business model has little impact on performance. Improving the model to a fully functional state has a slightly greater effect on performance than improving the quality of its individual blocks.

A number of factors that negatively affect the development, performance and sustainability of start-up can only be eliminated by partnering, since start-ups are naturally extremely limited in their resources. This is a difficult decision, however, because it means to make know-how accessible to partners or share control of the company and lose the independent and exclusive position of the founder. Weakening the key person's motivation will greatly affect the viability of the start-up.

The limitation of the research was the size of the research sample, which was given by the low helpfulness of the start-uppers. However, the size of the research sample enabled to do the pilot qualitative research and basic statistical analysis. Limited number of the studied bodies had been balanced by in-depth qualitative insight which 


\section{ENTREPRENEURSHIP AND SUSTAINABILITY ISSUES}

ISSN 2345-0282 (online) http://jssidoi.org/jesi/

2021 Volume 8 Number 4 (June)

https://doi.org/10.9770/jesi.2021.8.4(2)

can be enlarged in the next studies. The industry diversity of start-ups can also be a questionable limitation of research, but it is extremely difficult to compile a homogeneous sample.

Further research on start-ups, which would continue in topic to improve and increase their business sustainability, should focus on partnership (types, relationships, consequences), scaling (transition to scale-up) and innovation in monetization (use of platforms and shared economy).

Appendix 1 List of studied start-ups

Addwork - IT application, video job descriptions

Beesafe - IT application, personal security

eDocu - IT application, concentrated data about an object

elearn.aero - special education

GA Drilling - technology, deep earth drilling

Greenway - technology, e-mobility

Challengest - IT application, industrial production

iBed Pro - technology, special furniture

JobAngels - IT application, admin support

KickResume - IT application, compiling an attractive CV

Luigi's Box - IT application, search engine for e-commerce

Mapilary - IT application, tracking the distribution of goods at the last mile

Matsuko - IT application, human face identification

Microveg - technology, production and distribution of microherbs

Muvity - IT application, search for real estate agents

Octago - exercise equipment

Orderlord - IT application, ordering and food delivery

Quake resQ - technology, fast earthquake warning

Revolware - special consultancy for startuppers

RVMagnetics - technology, sensors

share.vi - technology, e-lock

Sli.do - IT application, feedback for public presentation

SkillsMill - personnel services, temporary insourcing specialists

Speekle - IT application, speech correction

Staffino - IT application, feedback on the quality of services and staff

Storyous - IT application, online cash register systems

Sufio - IT application, automatic invoices for online stores

3DRepo - technology, IT application, displaying large construction projects in 3D

Venzeo - admin support, photographic evidence of workflow or completed work

Green Mail - non-traditional postal services

\section{References}

Afuah, A. (2014). Business model innovation. Routledge. New York and London.

Blank, S., \& Dorf, B. (2012). The start-up owner's manual. The step-by-step guide for building a great company. K\&S Ranch Publishing Division, pp. XVII-XVIII.

Bliemel, M., Flores, R., De Klerk, S., \& Morgan P. Miles (2019). Accelerators as start-up infrastructure for entrepreneurial clusters. Entrepreneurship \& Regional Development, 31(1-2), 133-149. http://doi.org/10.1080/08985626.2018.1537152

Block, J. H., Kohn, K., Miller, D., \& Ullrich, K. (2014). Necessity Entrepreneurship and Competitive Strategy. IZA Discussion Papers, No. 8219, Institute for the Study of Labour (IZA): Bonn, pp. 1-32.

Booming Berlin. (2016). A closer look at Berlin's start-up scene. Research study, Institut für Strategieentwicklung (IFSE): Berlin, published in partnership with Factory Berlin, p. 9. 


\section{ENTREPRENEURSHIP AND SUSTAINABILITY ISSUES}

ISSN 2345-0282 (online) http://jssidoi.org/jesi/

2021 Volume 8 Number 4 (June)

https://doi.org/10.9770/jesi.2021.8.4(2)

Cavallo, A., Ghezzi, A., Colombelli, A. \& al. (2020). Agglomeration dynamics of innovative start-ups in Italy beyond the industrial district era. Int Entrep Manag J, 16, 239-262. http://doi.org/10.1080/08985626.2018.153715210.1007/s11365-018-0521-8

Crick, J. M., \& Crick, D. (2018). 'Lean Start-Up' Practices: Initial Internationalization and Evolving Business Models. In: Leonidou, L., Katsikeas, C., Samiee S., \& Aykol, B. (eds). Advances in Global Marketing. Springer, Cham. http://doi.org/10.1007/978-3-319-61385-7__2

Cooper, A., \& Folta, T. (2017). Entrepreneurship and High-technology Clusters. Chapter 17. http://doi.org/10.1002/9781405164214.ch17 In: Sexton, D. L., \& Landström, H. The Blackwell Handbook of Entrepreneurship. Blackwell Publishers.

http://doi.org/10.1002/9781405164214

Davila, A., Foster, G., He, X., \& Shimizu, C. (2015). The rise and fall of start-ups: Creation and destruction of revenue and jobs by young companies. Australian Journal of Management, 40(1), 6-35. http://doi.org/10.1177/0312896214525793

Dent, R. C., Karahan, F., Pugsley, B., \& Şahin, A. (2016). The role of start-ups in structural transformation. Staff Report, Federal Reserve Bank of New York, No. 762: New York. Available at:

https://www.newyorkfed.org/medialibrary/media/research/staff_reports/sr762.pdf?la=en (Accessed 5 November 2018)

Dömötör, R. et al. (2013). TwinEntrepreneurs Vienna-Bratislava, Regional Study. Available at:

http://www.twinentrepreneurs.eu/media/file/8_TwinEntrepreneurs_Regional_Study.pdf (Accessed 5 November 2019).

Euchner, J., \& Ganguly, A. (2014). Business Model Innovation in Practice. A systematic approach to business model innovation can help capture value and reduce risks. Research-Technology Management, 57(6), 33-39. http://doi.org/10.5437/08956308X5706013

finstat.sk. Available at: www.finstat.sk (Accessed 5 November 2019).

Foss, N. J., \& Saebi, T. (2017). Fifteen Years of Research on Business Model Innovation: How Far Have We Come, and Where Should We Go? Journal of Management, 43(1), 200-227. http://doi.org/10.1177/0149206316675927

Fritsch, M., \& Wyrwich, M. (2018). Regional knowledge, entrepreneurial culture, and innovative start-ups over time and space - an empirical investigation. Small Business Economics, 51, 337-353. http://doi.org/10.1007/s11187-018-0016-6

Garaj, P. (2015). Najbezpečnejšie investície? Firmy tridsiatnikov. (The best secure investment? Companies of thirty years men and women). Available at: https://www.etrend.sk/trend-archiv/rok-2015/cislo-48/pat-rokov-so-start-upmi.html (Accessed 11 October 2019)

Gassmann, O., Frankenberger, K., \& Csik, M. (2014). The business model navigator. Pearson.

Groesser, S. N., \& Jovy, N. (2016). Business model analysis using computational modelling: a strategy tool for exploration and decisionmaking. Journal of Management Control, 27(1), 61-88. http://doi.org/10.1007/s00187-015-0222-1

Hudáková, M., Urbancová, H., \& Vnoučková, L. (2019). Key Criteria and Competences Defining the Sustainability of Start-Up Teams and Projects in the Incubation and Acceleration Phase. Sustainability, 11, 6720. http://doi.org/10.3390/su11236720

Hunady, J., Orviska, M., \& Pisar, P. (2018). The Effect of Higher Education on Entrepreneurial Activities and Starting Up Successful Businesses. Inzinerine Ekonomika-Engineering Economics, 29(2), 226-235. http://doi.org/10.5755/j01.ee.29.2.19069

Johnson, M. W., Christensen, C. M., \& Kagermann, H. (2008). Reinventing Your Business Model. Harvard Business Review, Vol. 86 No.12, pp. 51-59. Avaailable at: https://hbr.org/2008/12/reinventing-your-business-model, (Accessed 5 November 2019)

Klačmer Čalopa, M., Horvat, J., \& Lalić, M. (2014). Analysis of financing sources for start-up companies. Management, 19(2), pp. 19-44. Available at: http://moj.efst.hr/management/Vol19No2-2014/3-KlacmerCalopa_et_al.pdf (Accessed 5 November 2018)

Kopera, S., Wsendybył-Skulska, E., Cebulak, J., \& Grabowski, S. (2018). Interdisciplinarity in tech start-ups development - case study of 'UniStartApp' project. Foundations of Management, 10, 23-32. http://doi.org/10.2478/fman-2018-0003 


\section{ENTREPRENEURSHIP AND SUSTAINABILITY ISSUES}

ISSN 2345-0282 (online) http://jssidoi.org/jesi/

2021 Volume 8 Number 4 (June)

https://doi.org/10.9770/jesi.2021.8.4(2)

Korhonen, H. M. E., Still, K., Seppanen, M., Kumpulainen, M., Suominen, A., \& Valkokari, K. (2017). The Core Interaction of Platforms: How Start-ups Connect Users and Producers. Technology Innovation Management Review, 7(9), 17-29. http://doi.org/10.22215/timreview/1103

KPMG. (2014). Prieskum slovenského startup ekosystému. (Survey of Slovak start-up ecosystem). KPMG na Slovensku: Bratislava, p. 34. Available at: https://assets.kpmg/content/dam/kpmg/sk/pdf/Startup-survey-2014-SK.pdf (Accessed 5 November 2018)

KPMG. (2016). Start-up ecosystem survey Slovakia 2016. KPMG in Slovakia: Bratislava, p. 3. Available at: https://assets.kpmg/content/dam/kpmg/pdf/2016/06/startup-ecosystem-survey-slovakia-2016.pdf (Accessed 5 November 2018)

Laerd Statistics. Available at: http://statistics.laerd.com/statistical-guides/pearson-correlation-coefficient-statistical-guide.php (Accessed 5 November 2019)

Lee, W., \& Kim, B. (2019). Business Sustainability of Start-Ups Based on Government Support: An Empirical Study of Korean Start-Ups. Sustainability, 11, 4851. http://doi.org/10.3390/su11184851

Malmström, M., \& Johansson, J. (2017). Practicing Business Model Management in New Ventures. Journal of Business Models, Vol. 5 No. 1, pp. 1-13. Available at: https://www.diva-portal.org/smash/get/diva2:1144729/FULLTEXT01.pdf (Accessed 15 November 2018)

Norman, G. (2010). Likert scales, levels of measurement and the "laws" of statistics. Advances in health sciences education, 5(5), 625-632. https://doi.org/10.1007/s10459-010-9222-y

Osterwalder, A., \& Pigneur, Y. (2009). Business Model Generation. Self Published, pp. 5-44.

Pettersen, I. B., Aarstad, J., Høvig, Ø. S., \& Tobiassen, A. E. (2016). Business incubation and the network resources of start-ups. Journal of Innovation and Entrepreneurship, 5(7), 1-17. http://doi.org/10.1186/s13731-016-0038-8

Ries, E. (2011). The lean start-up. Crown Business: New York, p. 27.

Rydehell, H., \& Isaksson, A. (2016). Initial Configurations and Business Models in New Technology-based firms. Journal of Business Models, Vol. 4 No. 1, pp. 63-83. Available at:

https://www.researchgate.net/publication/313249783_Initial_Configurations_and_Business_Models_in_New_Technology-Based_Firms (Accessed 5 November 2018)

Sedlacek, P., \& Sterk, V. (2014). The growth potential of start-ups over the business cycle. CFM discussion paper series, CFM-DP2014-3. Centre for Macroeconomics: London. Available at: http://eprints.lse.ac.uk/58223/ (Accessed on 15 November 2018).

Slávik, Š. (2019). The Business Model of Start-Up - Structure and Consequences. Adm. Sci. 9, 69. http://doi.org/10.3390/admsci9030069

SPEEDINVEST. Available at: https://speedinvest.com/ (Accessed 5 November 2018)

Teece, D. J., \& Linden, G. (2017). Business models, value capture, and the digital enterprise, Journal of Organization Design, 6(8), 1-14. http://doi.org/10.1186/s41469-017-0018-X

Thanedar, N. (2012). Are You Building A Small Business or Start-up? Available at: http://www.forbes.com/sites/theyec/2012/08/15/are-you-building-a-smallbusiness-or-a-startup/ (Accessed 3 September 2015).

Thiel, P. (2014). Zero to one. Notes on start-ups, or how to build the future. Crown Business: New York, 10-11.

Voinea, C. L., Logger, M., Rauf, F., \& Roijakkers, N. (2019). Drivers for Sustainable Business Models in Start-Ups: Multiple Case Studies. Sustainability, 11, 6884. http://doi.org/10.3390/su11246884 


\section{ENTREPRENEURSHIP AND SUSTAINABILITY ISSUES}

ISSN 2345-0282 (online) http://jssidoi.org/jesi/

2021 Volume 8 Number 4 (June)

https://doi.org/10.9770/jesi.2021.8.4(2)

\section{Acknowledgements}

This research was supported by the Nadácia Manažér/Foundation of Manager, Faculty of Business Management, University of Economics in Bratislava, Slovak Republic, grant number 1/18. In addition, this research was supported by the Scientific grant agency of Ministry of Education of Slovak Republic and Slovak Academy of Sciences (VEGA), grant number 1/0063/19.

Štefan SLÁVIK is the Professor of Business Management at Department of Management, University of Economics in Bratislava, Slovakia. He has long been involved in the research of business models and start-ups. Research interests: strategic management, management of change, business models, start-ups and entrepreneurship.

ORCID ID: https://orcid.org/0000-0002-2890-8091

Richard BEDNÁR is the Assistant Professor at Department of Management, University of Economics in Bratislava, Slovakia. He has long been involved in the research of business models and start-ups. Research interests: international management and business, general management, business models, start-ups and entrepreneurship.

ORCID ID: https://orcid.org/0000-0001-5282-6507

Ivana Mišúnová HUDÁKOVÁ is the Associate Professor at Department of Management, University of Economics in Bratislava, Slovakia. She has long been involved in the research of business models and start-ups. Research interests: strategic management, general management, business models and start-ups.

ORCID ID: https://orcid.org/0000-0001-8417-9762

Branislav ZAGORŠEK is the Assistant Professor at Department of Management, University of Economics in Bratislava, Slovakia. He has long been involved in the research of business models and start-ups. Research interests: business planning, general management, business models and entrepreneurship.

ORCID ID: https://orcid.org/0000-0003-3474-9442

Make your research more visible, join the Twitter account of ENTREPRENEURSHIP AND SUSTAINABILITY ISSUES: @Entrepr69728810

Copyright (C) 2021 by author(s) and VsI Entrepreneurship and Sustainability Center

This work is licensed under the Creative Commons Attribution International License (CC BY).

http://creativecommons.org/licenses/by/4.0/

(c) (†) Open Access 